\title{
Panen Mart's Existence in using Marketing Communication Strategies of Selling Agriculture Products
}

\author{
Aulia Adisti Indah Sari', M H Jamil'²,Munizu M³, Sri Undai Nurbaini³, Mahyuddin², Jusni³ \\ ${ }^{1}$ Student of Department Agribusiness, Graduated School Universitas Hasanuddin \\ ${ }^{2}$ Lecturer of Departmen Social-Economy of Agriculture Study Program, Faculty of Agriculture, Hasanuddin University, Makassar, Indonesia \\ ${ }^{3}$ Lecuterer of Departmen Management, Faculty of Economics and Business, Hasanuddin University, Makassar, Indonesia
}

Correspondence Author: Aulia Adisti Indah Sari, Student of Department Agribusiness, Graduated School Universitas Hasanuddin Email: adistiindah@gmail.com

Received date: 28 August 2019, Accepted date: 2 December 2019, Online date: 20 December 2019

Copyright: (C) 2019 Aulia Adisti Indah Sari et al., This is an open-access article distributed under the terms of the Creative Commons Attribution License, which permits unrestricted use, distribution, and reproduction in any medium, provided the original author and source are credited.

\begin{abstract}
The purpose of this study is to describe and explain the existence of a panenmart company in the marketing communication process. The analytical method used is a qualitative descriptive analysis Miles and Huberman with a case study approach for the selection of research sites and identification of informants through in-depth interviews with key informants including: Chief Technology Officer, Chief Business Development Officer, Chief Operation Officer, Chief Technology Officer, and Head of Content Digital Marketing and 3 (three) employees involved in the marketing communication process. The results of this study enable the panenmart company to maintain its existence by using five (5) elements of marketing communication, namely: media advertising, direct marketing, sales promotion, personal selling, interactive marketing.
\end{abstract}

Keywords: Existence, Agricultural Products, Marketing Communication

\section{INTRODUCTION}

Marketing and communication are two inseparable things. Marketing activities cannot run well without a proper connection within them. The agriculture sector plays a vital role in stabilizing the economic bases of developing countries. Since the agriculture sectors important in providing food needs of the population, supplying the raw material for industries, employment, and income generation, sustainability and stability of the agriculture sector is among the major factors contributing to social stability and economic growth of the society [1]. To find a capital loan is still in doubt. Some of the efforts that have been made are providing training to them on business development and offering to participate in exhibitions that are often held by local governments. But still, there were those who did not attend the event. consumers today were increasingly demanding high quality, cheap and fast delivery products. [2] Through marketing, the level of customer expands. However, through a marketing audit, an organization can be justified [3]. Marketing strategy has a significant role in the stage of forming consumer awareness and understanding. Every business person needs the right strategic planning so that the community can easily accept it. Marketing strategies are not only used to introduce the existence of a product but also provide knowledge about the benefits of the product being marketed to create a desire to buy it [4]. The term for the most popular online business is e-commerce. Ecommerce covers all business activities, from purchasing, manufacturing, marketing through sales, ordering, shipping, customer service, post-purchase programs and adding inventory. The use of e-commerce also provides opportunities for the emergence of e-purchasing and e-marketing [5].

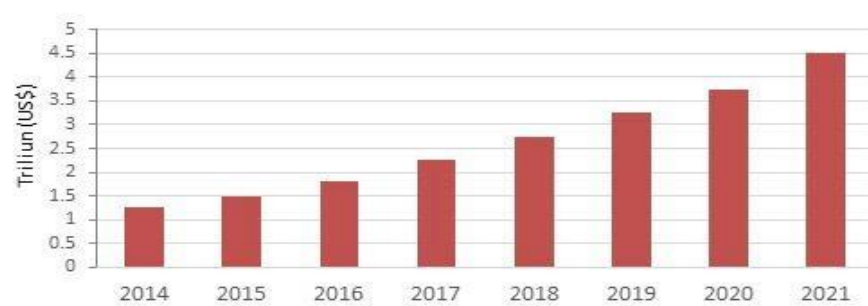

Graph 1. Development of E-Commerce since 2014 - 2021 Source: katadata.co.id (accessed on July 5, 2019) 
Online business has become a trend and is increasingly needed in the future. Companies are frequently doing business activities by utilizing information and communication technology. This is because consumers are increasingly aware of the ease of transacting with the internet. The choice of marketing communication decisions through internet promotion media is essential because of the high level of competition. Companies are required to be more creative in planning promotional programs that not only attract internet users to visit their sites but are also willing to make online purchases. If the distance between producers and consumers is relatively far, then the marketing channel is relatively long [6]. Now e-commerce is here to break the marketing channel chain.

This revolutionary way of e-commerce business transactions becomes an opportunity for PanenMart Company. PanenMart is a social enterprise that develops technology solutions and information systems, especially farmers and the people of Indonesia. By displaying superior products of horticultural commodities through mobile-based applications.

Graph 2. Transaction Data PanenMart Company

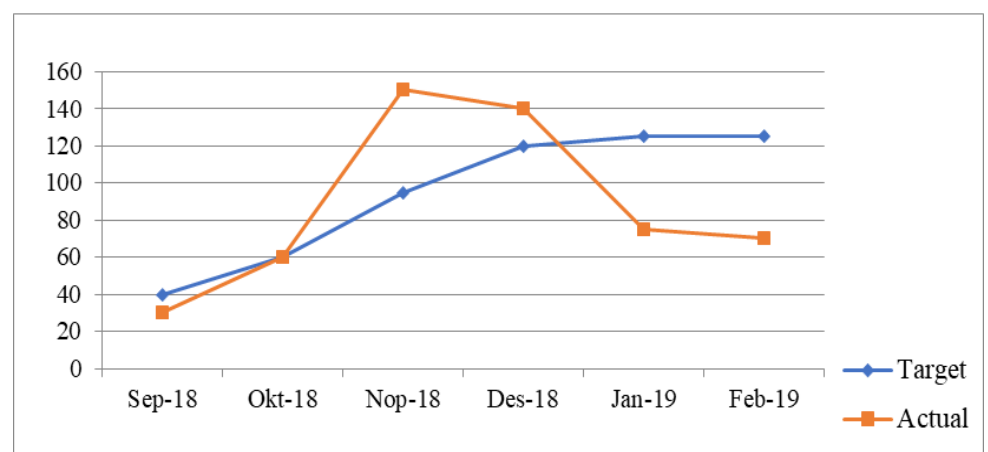

Source: PanenMart Company (2019)

Figure 2 shows that the growth in transaction rates during the past six months peaked in November 2018 which was conducted online. But there was a decrease in the level of transactions from January to February 2019 from the sales target.

\section{RESEARCH METHODS}

The data that have been obtained, both primary and secondary data, are then analyzed quantitatively and qualitatively, to illustrate the existence of the PanenMart Makassar Company using the following methods:

A. Descriptive Analysis

According to Miles and Huberman suggested that the activities in qualitative data analysis are carried out interactively and continue continuously until they are bored. Data analysis techniques include three components of the study, namely:

a. Data reduction

Data reduction is one of the qualitative data analysis techniques which is a form of commentary that sharpens, classifies, directs, discards unnecessary and organizes data so that conclusions can be drawn. Data reduction, by summarizing, choosing main points, is arranged more systematically, so that the data can provide a clearer picture of the observations and make it easier for researchers to find back the data obtained when needed.

b. Data Presentation

Presentation of data, to see the overall picture of the data or certain parts of the study. Thus the researcher can master the data more easily its truth by obtaining the data from other data sources, for example, from the second, third parties, and so on using different methods. Triangulation can be done using different ways, for example, by observation, interview and documentation. With this triangulation not only assesses the truth of the data but also can investigate the validity of the author's interpretation of the data, then the existing data will provide a reflective nature and ultimately with this triangulation will give the possibility that the first lack of information can add to the completeness from the previous data. The ultimate goal of this triangulation is to compare information about the same things obtained from various parties so that there is a guarantee about the level of data confidence.

c. Data Verification and Withdrawal of Conclusions

The third step of qualitative research is drawing conclusions and verification. The initial conclusions put forward are still temporary and change if no strong evidence is found to support the next stage of data collection. However, if the conclusions are indeed supported by valid and consistent evidence when the researcher returns to the field to collect data, then the conclusions obtained are conclusions that can be trusted.

Thus the conclusions in qualitative research may be able to answer the problem formulation that was formulated from the beginning, but maybe not. Because the problems and problem formulations in qualitative research are still temporary and will develop after researchers are in the field. The stages in data analysis above are inseparable parts, so they are interconnected between stages one and another stages. The analysis is carried out continuously from the beginning to the end of the study, to find out how the marketing communication mix is carried out by the PanenMart Company in maintaining the company's existence 
The analytical method used is a descriptive qualitative analysis with a case study approach to the selection of research sites and the determination of informants by means of in-depth interviews with key informants consisting of: Chief Executive Officer, Chief Technology Officer, Chief Business Development Officer, Head of Content Digital Marketing and 5 (five) employees involved in the marketing process

\section{A. Company Overview \\ 1. Company Profile}

\section{RESULT AND DISCUSSION}

PanenMart Makassar is a company in the form of Commanditer Venootschap (CV) which is engaged in supplying Vegetables and its processed products, where PanenMart Makassar is a subsidiary of PT. Solusi Agro Nusantara is also involved in agricultural products. Established since June 21, 2016, PanenMart Makassar is a social enterprise that develops technology and information system solutions, especially farmers and the people of Indonesia. Through a mobile-based application, PanenMart Makassar strives to provide online food product trading solutions to achieve food price stability by shortening the distribution chain from farmers to end consumers and helping farmers to increase their access to markets so that farmers as producers become a more equitable position and consumers can enjoy fresh food directly from farmers.

\section{Information Characteristics}

In this section, the results of the study are fully explained in terms of the characteristics of the respondents. The results of descriptive analyses that describe the characteristics of respondents based on gender, age, level of education, and years of service in full are presented in Table 2

Table 2. Description of Information by Gender, Age, Education Level and Years of Service

\begin{tabular}{|c|c|c|c|}
\hline No & Uranian & $\begin{array}{c}\text { Frekuensi } \\
\text { (Orang) }\end{array}$ & $\begin{array}{c}\text { Presents } \\
(\%)\end{array}$ \\
\hline \multirow[t]{4}{*}{ I. } & Gender & & \\
\hline & - Male & 7 & 77 \\
\hline & - Female & 2 & 22 \\
\hline & Total & & 100 \\
\hline \multirow[t]{6}{*}{ II. } & Age & & \\
\hline & - Under 20 & - & \\
\hline & $-20-30$ & 9 & 100 \\
\hline & $-31-40$ & & \\
\hline & $-41-50$ & - & - \\
\hline & - Over 50 & - & - \\
\hline \multicolumn{2}{|r|}{ Total } & 9 & 100 \\
\hline \multirow[t]{6}{*}{ III. } & Educations & & \\
\hline & - Senior High School & - & - \\
\hline & - Diploma & - & - \\
\hline & - Bachelor (S1) & 7 & 64 \\
\hline & - Magister (S2) & 2 & 22 \\
\hline & Total & 9 & 100 \\
\hline \multirow{5}{*}{ IV. } & Year of Service (year) & & \\
\hline & - Under 1 & 2 & 22 \\
\hline & $-1-2$ & 2 & 22 \\
\hline & $-2-3$ & 4 & 44 \\
\hline & Total & 9 & 100 \\
\hline
\end{tabular}

Source: Data Primary Data After Processing, 2019

Table 8 shows that the informants of this study were dominated by male employees, as many as 7 people (77 percent) and the rest were women by 2 people (22 percent). In terms of age, respondents in this study are predominantly in the productive age category, which is 20-30 years (77 percent) and 31-40 years (11 percent).

The dominant informant's education level is at the undergraduate degree (S1), which is 7 people (77 percent), and the remaining Masters are 1 person (11 percent). According to tenure, the dominant respondent had a work period of 2 to 3 years namely 4 people ( 44 percent), respondents who had a work period of under one year ( 22 percent), and above 1 year (22 percent).

\section{B. Panen Mart Marketing Mix}

Marketing mix strategy is one of the basic concepts in the modern marketing theory, which has received considerable academic and business industry attention. The marketing mix elements are product planning, pricing, distribution channels (places), and promotions. This marketing mix is interconnected and influential with each other so that it can cause satisfaction for consumers. The following is the marketing mix used by PanenMart Makassar 
1) Products

As an agricultural product e-commerce company in Makassar, harvestman provides a variety of agricultural products with four categories that can be seen in table 3 .

Table 3. Vegetable Category and Vegetable Supplier Area at the Panenmart Company

\begin{tabular}{|c|c|c|}
\hline No & Varieties of Vegetable & Supplier Area \\
\hline & Leaf Vegetable Category & \\
\hline 1 & Spinach & Bantaeng \\
\hline 2 & Toge & Makassar \\
\hline 3 & Cauliflower & Malino, Bantaeng \\
\hline 4 & Broccoli & Bantaeng \\
\hline 5 & Chinese Cabbage & Malino \\
\hline 6 & Mustard Greens & Malino \\
\hline 7 & Long Beans & Malino \\
\hline 8 & Kacang Panjang & Bantaeng \\
\hline \multirow[t]{2}{*}{9} & Cabbage & Malino \\
\hline & Fruit Vegetable Category & \\
\hline 1 & Bitter Melon & Malino \\
\hline 2 & Corn & Bantaeng \\
\hline 3 & Big Chili & Bantaeng \\
\hline 4 & Cayenne Pepper & Bantaeng \\
\hline 5 & Tomatto & Malino \\
\hline 6 & Bean & Bantaeng \\
\hline 7 & Eggplant & Bantaeng \\
\hline 8 & Lemon & Takalar \\
\hline 9 & Jackfruit & Bantaeng \\
\hline \multirow[t]{2}{*}{10} & Chayote & Bantaeng \\
\hline & Seasoning Category & \\
\hline 1 & Lime & Takalar \\
\hline 2 & Onion & Bantaeng \\
\hline 3 & Garlic & Bantaeng \\
\hline \multirow[t]{2}{*}{4} & Leek & Bantaeng \\
\hline & Tuber Category & \\
\hline 1 & Potato & Malino, Bantaeng \\
\hline 2 & Carrot & Malino, Bantaeng \\
\hline
\end{tabular}

Source: PanenMart Company Data, 2019.

In the table above, it can be seen that harvest selling various kinds of agricultural products with a number of 2 categories of vegetables and one category of herbs and one category of tubers, for example such as leaf vegetables, fruit vegetables, spices category, and tubers. For the category of Leaf Vegetables, there are nine types of vegetables, namely, Spinach, Toge, Cauliflower, Broccoli, White Mustard, Green Mustard, Kale, Long Beans, and Cabbage. Then for the category of Fruit Vegetables, namely Bitter Melon, Corn, Large Chillies, Hot Pepper, Tomato, Beans, Eggplant, Lemon, Young Jackfruit and Siam Pumpkin. As for the seasoning category, namely, Lime, Red Onion, Garlic and Green Onion. And for the tuber category, there are Potatoes and Carrots. The suppliers of raw materials for harvest companies are sourced from Malino, Bantaeng, Takalar and Makassar.

2) Price

The Panenmart Makassar company sets prices that are affordable and profitable for farmers and consumers alike because harvest harvests have cut long distribution chains. PanenMart buys $10 \%$ above the price of the middleman. So, the harvest from the farmers is taken directly to the Panenmart Company. The increased price is the cost of buying the product from the producer [8]. To see the price list set by the Panenmart company can be seen in table 4. 
Table 4. List of Prices of Vegetables by Category at Panenmart Companies

Source: PanenMart Company Data, 2019

\begin{tabular}{|c|c|c|c|}
\hline No & Varieties of Vegetable & Unit & Price (IDR) \\
\hline & Leaf Vegetable Category & & \\
\hline 1 & Spinach & Bundle & 1.500 \\
\hline 2 & Toge & Kilogram & 13.000 \\
\hline 3 & Cauliflower & Kilogram & 20.000 \\
\hline 4 & Broccoli & Kilogram & 25.000 \\
\hline 5 & Chinese Cabbage & Piece & 8.000 \\
\hline 6 & Mustard Greens & Kilogram & 24.000 \\
\hline 7 & Kale & Bundle & 2.000 \\
\hline 8 & Long Beans & Bundle & 1.500 \\
\hline \multirow[t]{2}{*}{9} & Cabbage & Piece & 8.000 \\
\hline & Fruit Vegetable Category & & \\
\hline 1 & Bitter Melon & Kilogram & 10.000 \\
\hline 2 & Corn & Piece & 3.000 \\
\hline 3 & Big Chili & Kilogram & 22.000 \\
\hline 4 & Cayene Pepper & Kilogram & 20.000 \\
\hline 5 & Tomatto & Kilogram & 8.000 \\
\hline 6 & Bean & Kilogram & 14.000 \\
\hline 7 & Eggplant & Piece & 2.000 \\
\hline 8 & Lemon & Kilogram & 55.000 \\
\hline 9 & Jackfruit & Kilogram & 11.000 \\
\hline \multirow[t]{2}{*}{10} & Chayote & Piece & 2.000 \\
\hline & Seasoning Category & & \\
\hline 1 & Lime & Kilogram & 20.000 \\
\hline 2 & Onion & Kilogram & 26.000 \\
\hline 3 & Garlic & Kilogram & 25.000 \\
\hline \multirow[t]{2}{*}{4} & Leek & Bundle & 6.000 \\
\hline & Tuber Category & & \\
\hline 1 & Potato & Kilogram & 10.000 \\
\hline 2 & Carrot & Kilogram & 8.000 \\
\hline
\end{tabular}

\section{Place.}

PanenMart, as an online company, does not have a physical store. PanenMart sells exclusively through the internet with the domain www.panenmart.com. Choosing a domain name is made as easy as possible for consumers to memorize it. This is important so that consumers can easily type the address in the browser. The domain used by panemart is the gTLD type. Most commercial companies in Indonesia use gTLD as a domain. In addition to the website, harvest also has mobile apps available on Playstore on Android gadgets. However, harvestman has an office in the form of Co-Working Space Digital Valley and also has a warehouse to store goods in different places.

3) Promotion

Promotion activities carried out by PanenMart are digital-based, namely direct selling (e-commerce) and also through Instagram social media.

\section{The Existence of The PanenMart Company}

Marketing communications requires an approach that is easy and flexible. It is all contained in the concept of the marketing mix. The marketing mix is a product strategy, promotion, and pricing that is unique and designed to generate an exchange of favors with the intended market [9]. Marketing communications have several elements that combined are embodied in the integrated marketing communications mix, marketing mix. Marketing mix elements are product, price, place/distribution and promotion. Maintaining the company's existence is very dependent on how a marketer can read and recognize rather than the desires and wishes of consumers. That way will have an impact on the company, the effect is the company can still run even though time continues to run because it can make the goods to be offered by the public is not inferior to the items offered by competing companies. The thing that is done by harvest companies in maintaining their company's existence is by using the marketing communication mix. 
a. Marketing Communication

according to Mahmud Machfoedz defines marketing communication strategies. Marketing communications requires an approach that is easy and flexible. It is all contained in the concept of the marketing mix. The marketing mix is a product strategy, promotion, and pricing that is unique and designed to generate an exchange of favors with the intended market. Marketing communications have several elements that combined are embodied in the integrated marketing communications mix, marketing mix. Marketing mix elements are product, price, place/distribution and promotion. Determination of a marketing promotion goal and marketing promotion goals made by a company. Making a marketing message design and marketing media through the development of a marketing mix to provide marketing budgets, to achieve an evaluation and control of appropriate and beneficial marketing plans [10].

To conduct effective marketing, PanenMart companies use marketing communication channels so that the products sold can be better known and known and reach more widely by consumers and potential customers. In this stage, harvestman uses 6 (six elements) marketing communication such as:

1) Digital Media Advertising

Digital Media Advertising is a medium that is used as a system for advertising in the promotion. The Digital Media Advertising used by PanenMart is Instagram social media

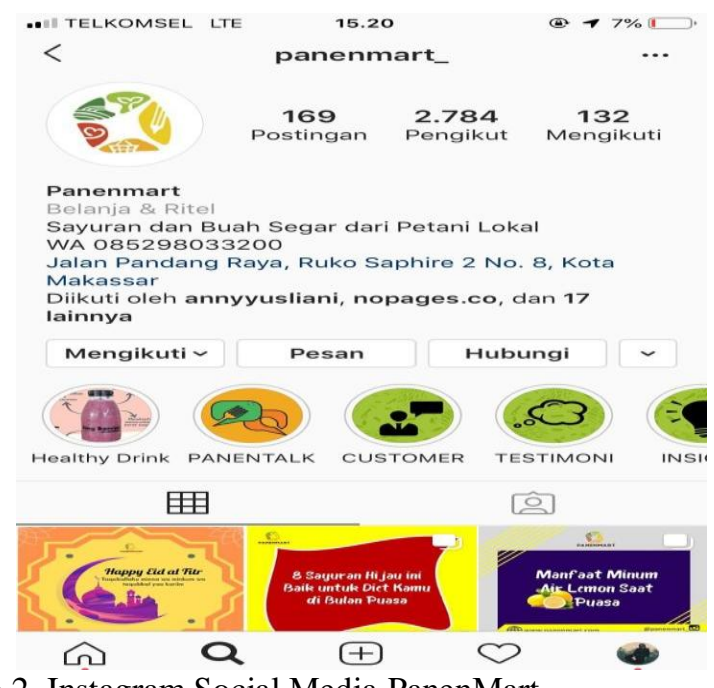

Figure 2. Instagram Social Media PanenMart

Instagram media is a digital tool used by harvestmart, because right now, Instagram has the most significant users. Even this step was taken by harvestmart as a means of using digital media advertising used username @ panenmart_.

2) Direct Marketing

Direct Marketing is a way of direct marketing using direct contact with customers or prospective customers. Using direct marketing will create a direct response to the target customer. There are several decision variables used in direct marketing, one of which uses the website.

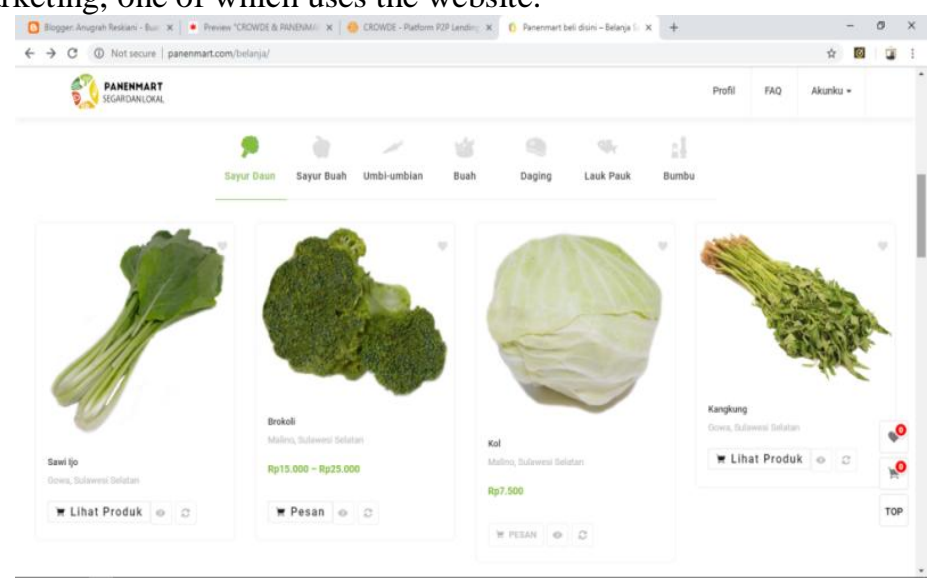

Figure 3. Website PanenMart Makassar

PanenMart uses the website as a way to direct marketing its products. By displaying agricultural products that he sells with visualization in the form of images and also accompanied by prices. The domain address for the PanenMart website is www.panenmart.com. On the website, there is also a feature FAQ (Frequently Answer and Question) for customers of website visitors.

3) Sales Promotion 
Sales promotion is a bidding system used to foster the attractiveness of consumers and potential customers. As for someone who has to conduct sales promotions is someone who has a communicative nature so that consumers understand and know the types of products offered. Because PanenMart is a business that engages in the digital field (e-commerce), PanenMart uses endorsement services for famous celebrities in Makassar.

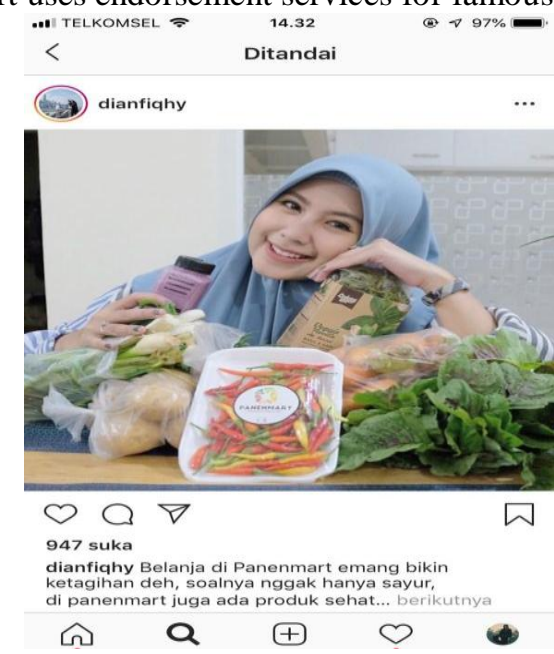

Figure 4. PanenMart's Sales Promotion Activity Using Influencer Services

PanenMart's sales promotion activities use the services of a well-known influencer in Makassar City. An influencer on behalf of @ dianfiqhy is one influencer who has 22,700 followers on his Instagram account. This method is one of the effective ways to introduce and also influence potential customers to know PanenMart better and also to captivate the hearts of potential customers

4) Personal Selling

Personal selling is a direct face-to-face activity between the seller and the prospective buyer. PanenMart also often conducts direct sales to introduce PanenMart and at the same time educate prospective customers about the order process on the PanenMart website (e-commerce)

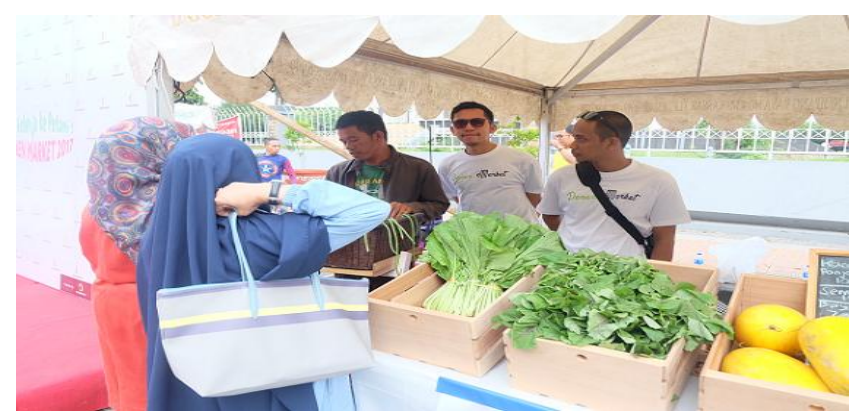

Figure 5. PanenMart Personal Selling Activity Process

This Personal Selling activity is a weekly activity that is often held by PanenMart Makassar. In addition to selling products, this activity is not infrequently; also the PanenMart workforce goes directly to educate buyers. Because the main goal of PanenMart is to introduce a market place that sells agricultural commodity products.

5) Interactive Marketing

Interactive Marketing System is a promotional tool to maintain good relations with consumers. One of the Interactive Marketing channels conducted by PanenMart is Word of Mouth (WOM).

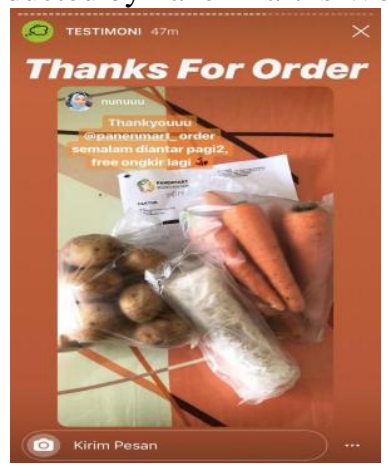

Figure 6. The Word of Mouth System Used by PanenMart

Word of Mouth is one part of interactive marketing used by PanenMart. PanenMart uses a testimonial system for every product purchased. So that PanenMart is more widely known by potential customers. 


\section{CONCLUSION}

In conducting the marketing system, PanenMart uses 5 (five) communication elements of the courier, namely, digital media advertising, direct marketing, sales promotion, personal selling, and interactive marketing. And Broadly speaking PanenMart uses the B2C (Business to Consumer) system in the process of marketing its products to maintain the PanenMart Company Existence.

\section{REFERENCES}

[1] Neda Jowkar, Nematolah Masovi dan Bahaedine Najafi, 2015. Management Strategy For Agricultural Development in the Khaerameh City Using SWOT Model. AENSI Journals. Advances in Environmental Biology, 10(6): 839-846. ISSN1816-9112

[2] SN Sirajuddin, AR Mappangaja, R Darma, I Sudirman. 2015. Value Added Analysis of Beef Cattle Supply Chain Actors Micro-Scale Community Farm Based. American-Eurasian Journal of Sustainable Agriculture 9 (7), 7-12.

[3] Mohammed Abdulellah Yousuf Saeed, et al, 2017. Constructing Model to Explore the Influence of Marketing Audit on Organizational Performance. Australian Journal of Basic and Applied Sciences, 11(15) December 2017, Pages: 83-90. AENSI Publisher.

[5] Tjiptono, Fanda and Gragerious Chandra, 2012. Pemasaran Strategik,

[4] Prawitra, T. 2000. E-Commerce Marketing : Business Imperative for Superior Customer Value. Jurnal Usahawan (9) : 26-32.

[5] Sirajuddin, SN. Aspek-Aspek Pengembangan Usaha Sapi Perah di Propinsi Sulawesi Selatan. Universitas Hasanuddin

[6] Drucker, Peter. 2000. Innovation. Jakarta: PT Gramedia Pustaka Utama

[8] Nawawi, Hadari. 2000. Manajemen Sumber Daya Manusia Bisnis yang Kompetitif, Gajah Mada University Press, Yogyakarta

[9] Retno Sari Mahanani, 2016. Advances in Environmental Biology, 10(8) August 2016, Pages: 132-139. AENSI Publisher.

[10] Machfoedz, Mahmud. Komunikasi Pemasaran Modern. Yogyakarta: Cakra, 2010 